\title{
ASSESSMENT OF MACROECONOMIC SITUATION AND ECONOMIC POLICY DURING THE CRISIS IN THE BALTIC COUNTRIES
}

\author{
Gediminas DAVULIS \\ Mykolas Romeris university \\ Ateities Str. 20, LT-08303 Vilnius, Lithuania \\ E-mail: geddav@mruni.eu \\ doi:10.13165/IE-13-7-3-03
}

\begin{abstract}
The article deals with the economic situation and state economic policy in Lithuania before and during the crisis. The pre-crisis period, i.e. 2004-2007, was characterised by rapid growth of the economies of Lithuania and other Baltic countries, which was unprecedented in post-war Europe. The growth of Lithuania's economy was interrupted by global economic and financial crises of 2008. Before and at the time of the crisis, the macroeconomic situation of Lithuania is analysed by using the statistical data of the Lithuanian Department of Statistics. It discusses the main factors that influenced the economic situation of the country and the means of governmental economic policy during the period under consideration. The article also presents the anti-crisis policy of the other Baltic countries. A comparative analysis of the macroeconomic situation in the Baltic countries is performed. The analysis showed that economic processes were similar without essential differences in all Baltic countries, with the exception of the spheres of public finances, where Estonia had an obvious advantage, compared to Lithuania and Latvia.
\end{abstract}

JEL classification: E60.

Keywords: anti-crisis measures, economic policy, global financial crisis, macroeconomic processes.

Reikšminiai žodžiai: antikrizinès priemonès, ekonominė politika, globalinė ekonomikos ir finansų krizè, makroekonominiai procesai.

\section{Introduction}

The article analyses Lithuania's economic situation and the economic policy of the country after Lithuania's accession to the European Union, i.e. after 2004. The period under consideration includes the pre-crisis and the crisis periods. The pre-crisis period, i.e. 2004-2007, was characterised by rapid economic growth of the Lithuanian economy. Decreasing unemployment, increasing income, hard currency and financial support of the EU were the main factors determining growth of the Lithuanian economy. Its growth was interrupted by the global economic and financial crises. The current financial crisis 
that struck the world affected the majority of the countries to a larger or smaller extent. Due to the economic crisis, the growth of economy in the EU countries slowed down considerably and the number of the unemployed seriously increased. The Baltic countries perhaps suffered the most and their economic depression was very painful. 2007 is considered as the onset of the current financial crisis, when the Federal Reserve System of the USA had to interfere and grant liquidity to the bank system (Soros, 2009). A famous American economist J. Stiglitz (2006) (Felton, Carman, 2008) noted the deteriorating economic situation of the country and wrote about a possible financial crisis in the USA before the onset.

The current global crisis is not the only worldwide crisis in the new history of humanity. We are aware of such economic crises that have affected more than one state and therefore they can be called global crises (Dash, 2001; Feldstein, 1991; Sylla, 2009; Davulis, 2012). The current global crisis stands out from the previous ones by its measures. It affected the majority of the world countries. In this respect, it has even surpassed the Great Depression of 1929-1933 (Eichengreen, Rourke, 2010). It should be stressed that the severe lessons of the Great Depression were not in vain and that the government's response to economic recession was much more expeditious than in 1929 (Romer, 2009). For example, in 2008, the European Commission (Commission of the European Communities, 2009) prepared an economy restoration plan, which implied the increase of demand by enlarging the purchasing capacity of the population and restoring the confidence of investors.

Regarding the causes of the current crisis, many of them can be enumerated. We shall limit only to two aspects, which, in our opinion, are essential, namely the disorder in stock exchange caused by collapse of the real estate bubble and globalisation of the world economy. The two aspects distinguish the current global crisis from the other crises. Modern financial markets are characterised by the use of extremely complicated derivative financial measures. Though such derivative measures were created in particular to diversify and diminish the risk, as the previous years showed that banks and investment companies had insufficiently assessed the risk. It was one of the causes of the current global financial and economic crisis and the processes in the real estate market were the detonator that invoked the global downturn.

Another important peculiarity of the current global crisis is the influence of globalisation processes on the spread of economic problems worldwide. Globalisation has both positive and negative consequences. Intensifying integration of financial markets is related to growing risk and uncertainty. Therefore, it is difficult to predict its consequences. At the same time, with the intensifying interrelations and interdependence of global financial markets and economies, the risk of problem transmission also increases.

The article discusses the factors that influenced fast growth of the Lithuanian economy in the pre-crisis period, the main causes of the global financial crisis as well as its effect on the Lithuanian economy and the measures of economic policy of the governments in the period under consideration. Based on statistical data, the macroeconomic condition of Lithuania and other Baltic countries is analysed during the period after 2004. Such investigation is meaningful for the sole purpose of avoiding future economic policy errors. 


\section{Macroeconomic Situation in Lithuania before the Crisis}

2004-2007 were the years of rapid economic growth for Lithuania, which, according Rosenberg, (2008) was unprecedented in post-war Europe. In this period, the country's GDP was growing steadily and in 2007 its growth rate reached 9.8\% (Fig. 1).

Figure 1. Yearly alteration of Lithuania's real GDP in 2004-2011 (in percentage terms)

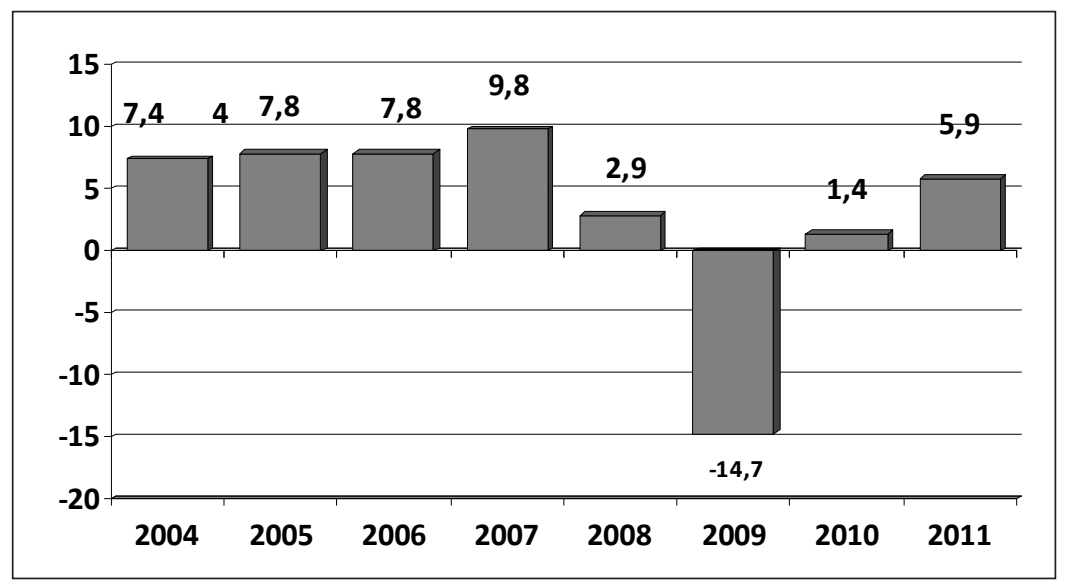

Source: Lithuanian Department of Statistics.

With the growth of economy from 2004 to 2007, unemployment also decreased constantly, with its level diminishing from 11.4\% in 2004 to $4.3 \%$ in 2007 (Fig. 2).

Figure 2. Unemployment level in Lithuania in 2004-2011 (\% of GDP)

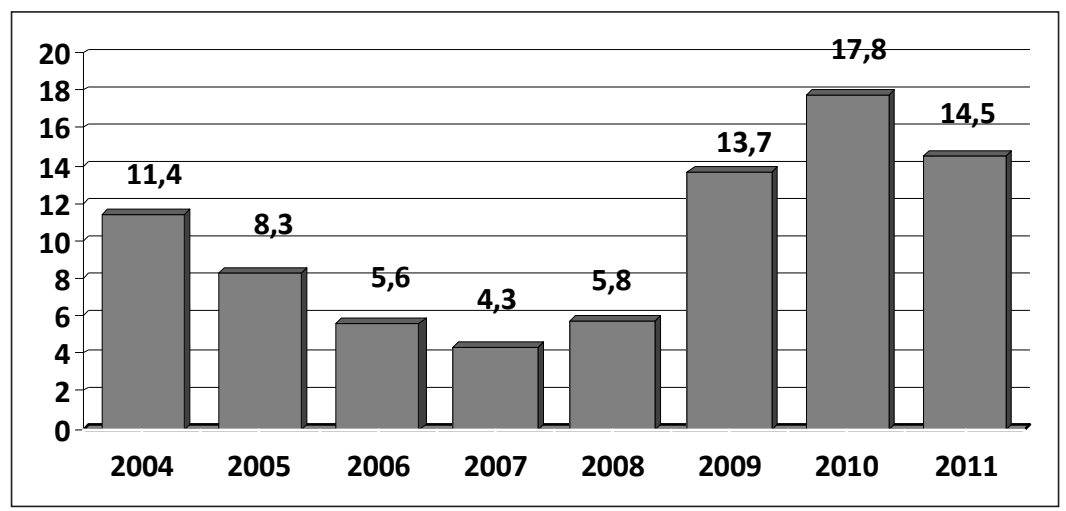

Source: Lithuanian Department of Statistics. 
Improving economic situation of the country, increasing employment and wages, favourable prospects of the country's future somewhat slowed down emigration streams in 2004-2006 (Fig. 3).

Figure 3. Dynamics of emigration from Lithuania in 2004-2011 (thou. of people)

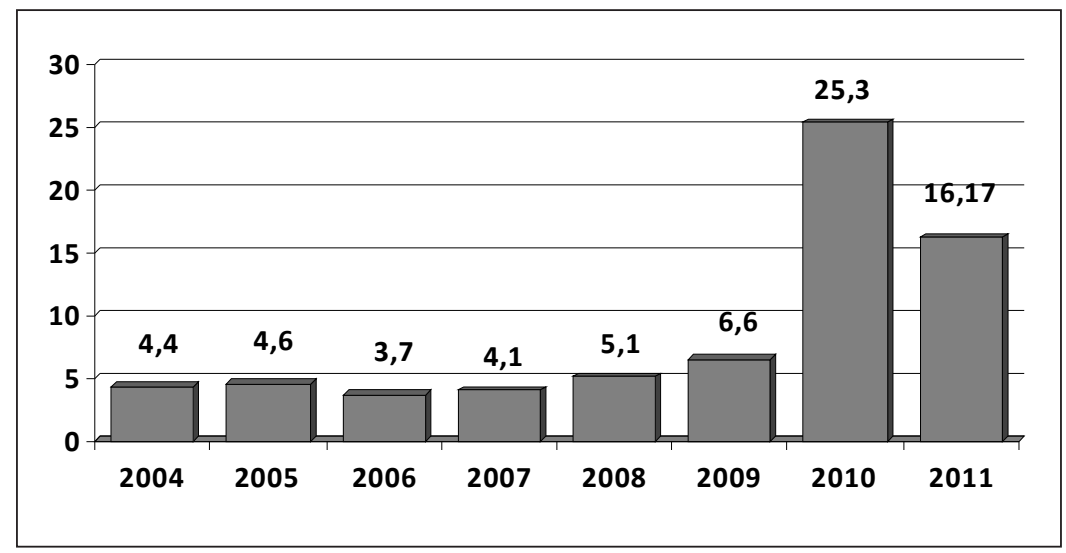

Source: Lithuanian Department of Statistics.

Growing economy of the country, favourable conjuncture of the international market with the rising needs for imported production of the other EU countries allowed us to uniformly increase the country's exported production volumes - in 2008, the country's export amounted to $25.5 \%$ of its GDP level.

Thus, at the onset of the crisis, Lithuania's economy was growing. Decreasing unemployment, increasing income, hard currency and financial support of the EU were the main growth factors. As evident at present, those factors laid the grounds for reasonable expectations as to the future of the country. Guided by those expectations, both enterprises and households began borrowing for consumption and business ever more and, more importantly, the banks issued loans with engaging interest (Fig. 4).

The largest share of loans received by households was aimed at the real estate market (Fig. 5). This process was stimulated by the state, granting tax privileges for housing loans, which in turn preconditioned the formation of the real estate bubble. According to the data of the Bank of Lithuania, the volume of loans to acquire housing comprised more than half of all loans for households in 2005 and 2006. It is obvious that such an expansion of credit had a decisive influence on the formation of a 'bubble' in the Lithuanian real estate market. 
Figure 4. The dynamics of new loans for business and households in Lithuania in 2004-2011 (milions of litas)

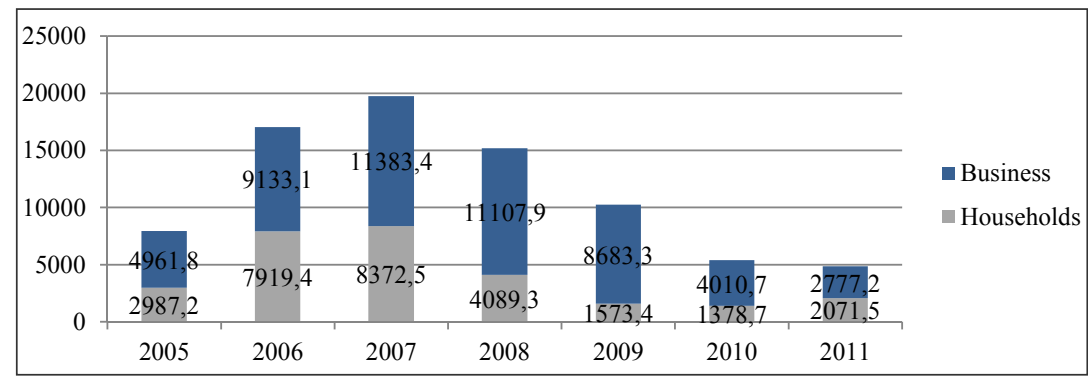

Source: Database of the Bank of Lithuania.

Figure 5. The dynamics of the structure of new loans for households in Lithuania in 2004-2011 (millions of litas)

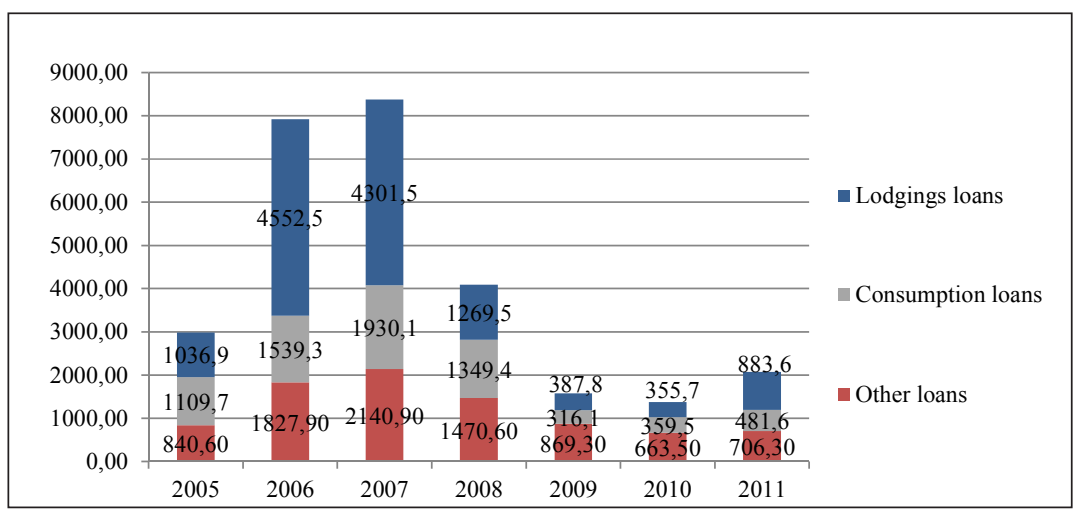

Source: Database of the Bank of Lithuania.

Thus, from 2004 up until the crisis, the Lithuanian economy was growing due to the growth of domestic demand, maintained by unfounded future expectations. The growth of domestic demand stimulated increase of import as well. However, the increase of import was not counterbalanced by adequate export increase, i.e. export volumes lagged behind from those of import until 2009 and thus the country's foreign trade balance was negative (Fig. 6). A constant foreign trade deficit also determined the growth of the current account deficit. According to the data of the Bank of Lithuania, from 2004 to 2007 the current account deficit of Lithuania grew to almost 300\% and exceeded LTL 14 billion.

Long before reaching Lithuania, the first signs of the global financial crisis appeared in the USA in 2007. As shown by the statistical data (Fig. 1), the country's GDP growth rate that reached almost $10 \%$ in 2007 fell down by $3 \%$ in 2008 and even by $15 \%$ 
in 2009, thus pushing Lithuania among the states that suffered from the crisis the most. For this reason, in 2008 the budget deficit amounted to $3.2 \%$ and in 2009 to nearly $9 \%$ of the country's GDP, i.e. it almost thrice exceeded the level set by the Maastricht Treaty. Only in the years of recovery of the country's economy, the state budget deficit began to decrease and at the end of 2011 it reached 3.3\% of the GDP, i.e. it slightly exceed the Maastricht criterion. With a downturn of production, unemployment began to rise in the country and in 2009 amounted to even $13.7 \%$ (Fig. 2), which became a serious problem for the country's economy. Emigration from the country also started increasing again and, according to the official data of the Lithuanian Department of Statistics, reached more than 25000 of emigrants in 2010 (Fig 3). Lithuania was not ready for that situation, as its strategy for economic development was based on macroeconomic stability and on the assumption of uniform economic growth (Rakauskiene, Krinickiene, 2009).

Figure 6. Foreign trade balance of Lithuania in 2004-2011 (\% of GDP)

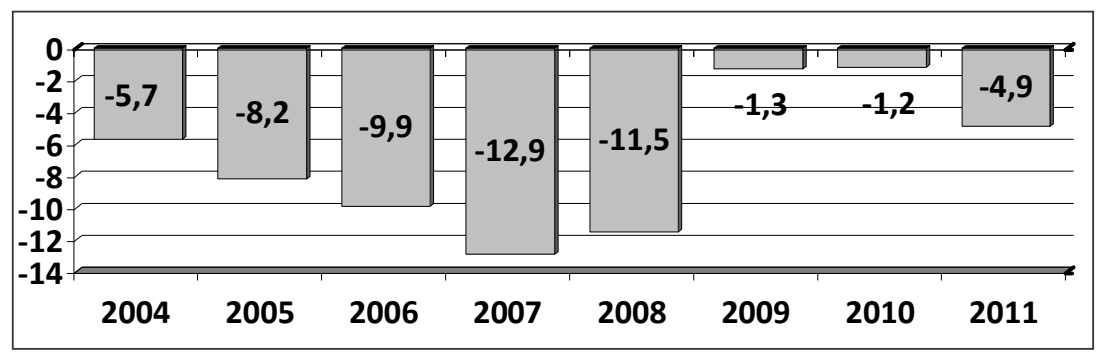

Source: Lithuanian Department of Statistics.

Constant foreign trade deficit also determined growth of the current account deficit. According to the data of the Bank of Lithuania, the current account deficit in Lithuania increased by almost 300\% from 2004 to 2007 and exceeded LTL 14 billion.

After the burst of the "bubble" in the Lithuanian real estate market, the credit interest applied by the banks operating in Lithuania also increased. That negatively affected the Lithuanian economic operators and a considerable number of enterprises went bankrupt. The economic depression could only be invoked by the processes taking place in the country's real estate market, however, our economy was mostly affected by external factors. Because of foreign trade balance (Fig. 6) and current account deficit of the country, in such a situation economic growth was feasible only by borrowing on the international financial market to cover the deficit. However, due to the global crisis, increased interest stopped the flow of foreign credit and shook the basis for the economic growth of the country. At the same time, the global crisis predetermined the slowdown of economic growth and decrease in consumption of many world countries. Decreasing consumption of foreign countries restricted the chances of the Lithuanian export and this was one of the most important factors that determined the country's economic depression. The domestic market of Lithuania is too small to maintain economic growth and to compensate the decrease in export. With the revival of the markets of foreign 
countries, Lithuania's possibilities have also improved. 2010 was the starting year for the recovery of Lithuania's economy - all of the main macroeconomic indicators began to increase slowly, but constantly.

Though the signs of the global crisis were evident rather early, Lithuania faced the crisis quite unprepared. Such a situation was predetermined by insufficient competence of our government, lack of responsibility, and possibly political reasons. As a result, Lithuania faced the crisis with chrome foreign trade and current account deficit, state and private sector debts and without any reserves accumulated.

Opponents often reproached the former government for unfoundedly raising salaries of public servants as well as the retirement pensions and for failure to accumulate financial reserves for tackling the most urgent problems arising during the crisis. In our opinion, the opponents are partially correct. At the same time, the most serious mistakes that the government made were elsewhere. It was indispensable to increase salaries with the view of avoiding the loss of the remaining good specialists. This measure proved to be correct: emigration was slackened and it even decreased (Fig. 3). Upon creating state welfare, pensioners also have the right to a certain level of well-being. Thus, the decisions to increase salaries and pensions were necessary and they truly improved the state welfare. At the same time, when making such decisions, the government did not provide for their constant financing, by taking a possible economic downturn into account.

Much more serious errors of the government were associated with public finances. Despite rather high GDP growth rates in the country, in 2004-2008 the expenditure of the government sector was exceeding its revenues year after year, i.e. there was a deficit state budget (Fig. 7).

Figure 7. Lithuanian state budget balance in 2004-2011 (\% of GDP)

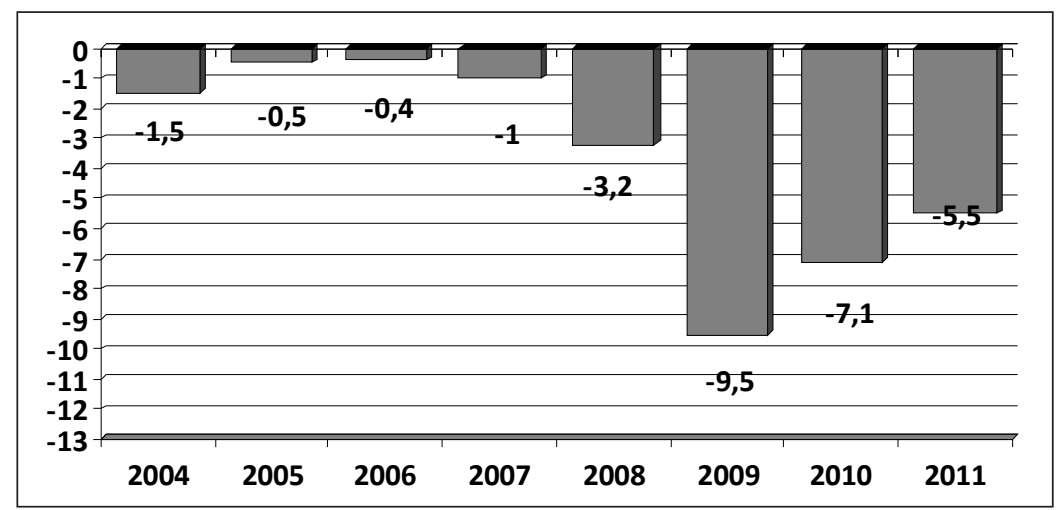

Source: Lithuanian Department of Statistics.

Though before the crisis the budget deficit was not that high, under the conditions of rapid economic growth it prompted economic overheat. At the same time, constant budget deficit increased the country's debt which was unacceptable under the conditions 
of economic growth. Meanwhile, budget surplus would not allow economic overheat and establish the conditions for accumulating the necessary reserves and financing the augmented state liabilities under the cyclic conditions of recession.

Another obvious error of the government was the reduction of taxes at the time of excessively rapid economic upturn, which was also contrary to the economic principles. The tax policy of that time had to be different - an opportunity was missed to impose a real estate tax (of course, by setting a tax-exempt minimum), luxury wealth tax and a progressive tax system. All of those measures could also accumulate the necessary financial sources to cover state expenses. Thus, the formation of the deficit budget and tax reduction in the years of rapid economic upturn were the most serious errors made by the government that caused painful consequences during the crisis.

The correct step of that government was the adoption of the Fiscal Discipline Law in 2007, aimed at ensuring financial stability and stable development of the economy. According to that Law, in 2008 the government sector deficit could not exceed $0.5 \%$ of GDP. Unfortunately, the Law was passed too late and its requirements could not be implemented with the onset of the crisis.

The Bank of Lithuania also failed to sufficiently estimate the scale of the pending crisis (Šarkinas, 2008). It declared that the direct impact of the global crisis on the financial system of the country could not be significant because it was not closely connected to the economic and financial links of the investment banks and other institutions of the USA. At the same time, after the Russian financial crisis in 1998, the supervision of commercial banks of the country was intensified, which ensured the stability of the Lithuanian financial system. However, the near future showed that the Bank of Lithuania was not quite correct and that the supervision of commercial banks was evidently insufficient (Jakeliūnas, 2010).

\section{Anti-Crisis Measures of the Lithuanian Institutions}

In the face of the crisis of 2008, the Bank of Lithuania and the Lithuanian Parliament adopted the following decisions: to lower the mandatory reserve rate from 6 to $4 \%$ and to increase the deposit insurance amount up to EUR 100.000 with a view to vivify the domestic market by using additional financial resources. Though those decisions were correct and were adopted in time, unfortunately, their effect seemed to be insufficient. To maintain market activity, more intensive promotion of the economy was necessary. However, due to an inadvertent and irresponsible budget policy persuaded by the years of economic upheaval, there were no resources to stimulate the economy. Therefore, nothing else could be done but to take measures that were often applied during economic growth and not at the time of depression. The newly elected Lithuanian Parliament and the Government undertook to apply the restrictive fiscal policy measures: decrease the expenditure and increase taxes in order to stabilise state finances, as persistently recommended by the European Commission.

At the end of 2008, a decision was made to increase the rate of value added taxes up to $19 \%$ (subsequently it was further increased up to $21 \%$ ), the income tax, the excise 
duty for fuel, cigarettes and alcohol, and to eliminate the majority of reduced tariffs of the value added tax. The so-called 'overnight' tax reform entered into force on 1 January 2009. The tax reform was aimed at collecting more budget income, expecting to stabilise the state financial system, rather than at neutralising the effects of the crisis on the economy. However, according to the statistical data, in 2009 the state budget received much less income than in 2008. Certainly, such a result was mostly predestined by the economic downturn, however, there was little doubt that the 'overnight' reform was not deliberate enough. Even the country's government acknowledged that the reform was incorrect in certain aspects. Possibly at that time there was some sense to increase the value added tax, however, the abolition of all privileges of that tax was a mistake: the budget lost a considerable part of income that went to the neighbouring countries. In principle, the increase of the profit tax rate was correct, but it had to be differentiated according to the economic branches and the size of a company, which was indeed accomplished at a later stage. The suggestion of the opponents that increase of the profit tax limited foreign investments was not very convincing. The research has shown (Davulis, 2003) that tax privileges do have some but little influence on the volume of foreign investment in the country's economy. The investors are much more concerned with the attractiveness of the investment objects. The consequences of increased excise duty also did not have single value for the economy.

Thus, the government had to adopt an undersubscribed decision - to pursue the so-called retrenchment policy, i.e., to diminish government expenses by lowering the employers' and officeholders' salaries, pensions and social benefits, and such policy was assessed ambiguously. On one hand, it allows diminishing government expenses, and on the other hand, it decreases income of the population and thereby lowers consumer demand. The decrease in demand increasingly weakens the domestic market. The domestic market will revive only if income of the population starts growing and consumer demand starts increasing. Straightforward decreasing of expenses in all spheres can only yield a short-term effect. Decreasing expenses for the activities that determine science and technology progress or development of infrastructure can cause negative long-term consequences for the country. Thus, the retrenchment policy should be deliberate enough and balanced.

Though Lithuania's macroeconomic situation started improving from 2010, in our opinion, it improved due to better situation on international markets and especially by reason of the recovery of foreign countries that imported goods of the Lithuanian producers rather than due to the actions of the government.

\section{Anti-Crisis Measures Undertaken in Other Baltic Countries}

At the end of 2008, the Latvian Saima approved the programme for the stabilisation and revival of the Latvian economy. The programme obliged the government to pursue strict fiscal policy decreasing the state budget deficit, to establish the stabilisation reserve into which money could be transmitted in case of the balanced budget and the growth of GDP exceeded $2 \%$. The structural reforms were foreseen in the plan in order to decrease public management expenses by $15 \%$, without reducing the financing for social protec- 
tion measures. The Bank of Latvia was obliged to keep the fixed ratio between the latas and the euro. In line with the programme, in 2009 the government of Latvia planned to decrease the resident income tax rate by $2 \%$, to increase the value added tax rate by $3 \%$, to eliminate the majority of reduced value added tax rates, to increase the excise duty for fuel, coffee and alcohol and to tax residential apartments as from 2010. In 2010, the Latvian government submitted a new plan for economic revival to the Saima. The plan provided for export stimulation, manufacturing of home commodities for replacing import, orientation of production to manufacture commodities with high added value and stimulation of the sectors of economy based on knowledge and innovations.

In 2008, the International Monetary Fund, the World Bank and the financial institutions of the EU issued a credit to Latvia for the reforms, amounting to EUR 7.5 billion (EUR 1.7 billion were granted by IMF). Although the creditors fixed low interest rate for the credit, they required to fulfil strict conditions, i.e. to decrease the state budget deficit to $3 \%$ of GDP in three years, not to increase pensions, to decrease salaries, to set new taxes, to diminish governmental management expenses by $30 \%$ instead of $15 \%$.

Thus, the anti-crisis measures were similar both in Latvia and Lithuania. The revival of the economy is based on strict fiscal policy and saving in both countries.

Estonia began to implement strict fiscal policy earlier than the other Baltic countries, i.e. before the beginning of the crisis. In the years of rapid economic growth, Estonia began forming a surplus state budget and accumulated fiscal reserves. The accumulated reserves allowed Estonia to avoid the necessity to borrow on the international financial markets and paying high interest rates at the time of the global crisis. Thus, the financial reserves accumulated before the start of the crisis permitted Estonia to gain obvious advantage, compared to the other Baltic countries. Although Estonia did not have a formal anti-crisis plan, as it expected to naturally overcome the economic difficulties, it was also forced to apply the saving mode. The Estonian government also decided to decrease the state expenditure, especially in the sphere of health protection and education, pensions and salaries (by 15\%), to increase the rate of the value added tax from 18 to $20 \%$, the excise duty on tobacco products and alcohol and to introduce new taxes.

\section{Macroeconomic Situation in the Baltic Countries during the Crisis: Comparative Analysis}

The analysis of the macroeconomic situation in the Baltic countries is based on the data of the Eurostat database. As mentioned above, for a number of years the Baltic countries were marked by a considerably faster economic growth than other EU Member States. Before the crisis, the maximum GDP growth rate amounted to almost $10 \%$ in Lithuania, almost $8 \%$ in Estonia and exceeded $12 \%$ in Latvia. However, as the global trade shrank as a result of the global economic crisis, the export-oriented economy of the Baltic countries plummeted to an all-time low: in 2009, the real GDP of those countries decreased between 14 to $18 \%$ (14\% in Estonia, 15\% in Lithuania and 18\% in Latvia), compared to the 2008 data. From 2010, the Baltic countries had already shown some signs of recovery in their economies (Fig. 8). 
Figure 8. The yearly alteration of real GDP in the Baltic countries in 2004-2011 (in percentage terms)

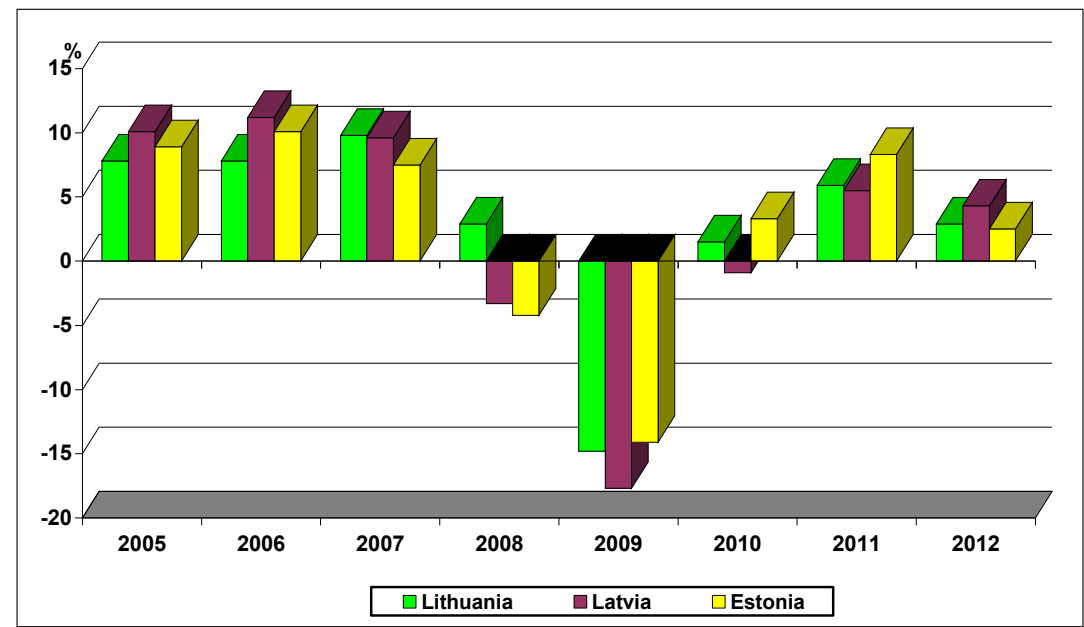

Source: Eurostat database.

Figure 9. Government deficit of the Baltic States in 2005-2010 (\% of GDP)

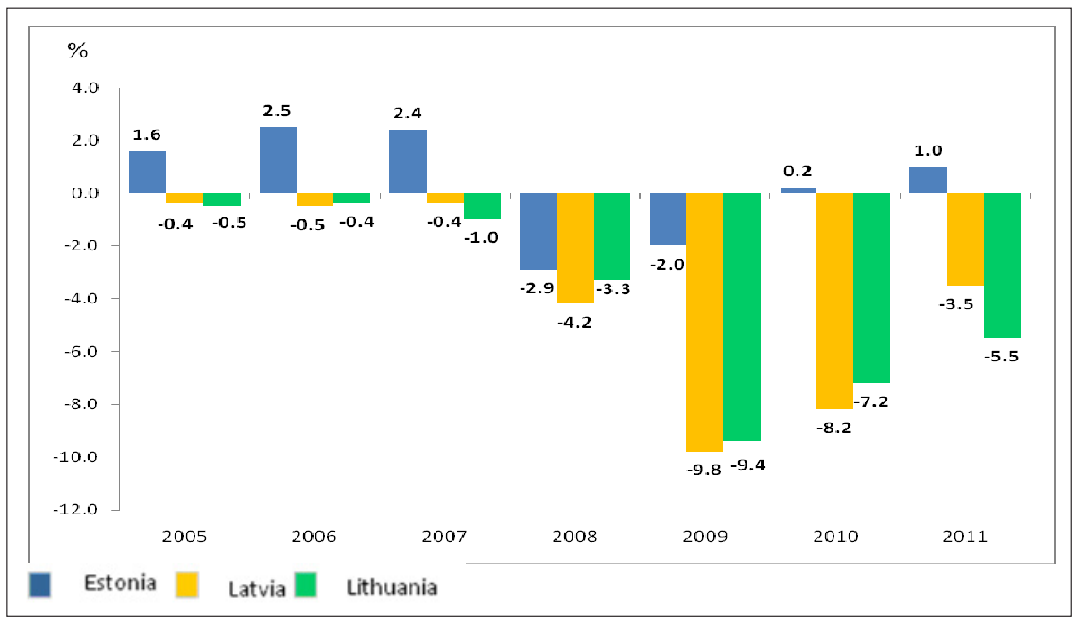

Source: Eurostat database.

Like many other EU Member States, Latvia and Lithuania were facing the budget deficit problem: the proportion of fiscal deficit to GDP largely exceeded the limit of 3\% prescribed by the Treaty of Maastricht $(9.5 \%$ in Lithuania and $9.7 \%$ in Latvia, but in 2010 
their fiscal deficit decreased to 7-8\% of GDP (Fig. 9). In 2009, the Estonian budget deficit remained as low as $2 \%$ of GDP. The Estonian budget was in surplus and amounted to $0.2 \%$ of GDP in 2010 and $1.0 \%$ of GDP in 2011. It nevertheless stayed within the limit of $3 \%$ of GDP, thereby satisfying the Maastricht criterion. Thus Estonia had no problems with budget deficit due to the accumulated reserves. However, one must admit here that Estonia did manage to maintain its financial discipline at the level likely to be envied by other much more economically powerful countries.

In 2010, the proportion of the government debt to GDP equalled to $44.7 \%$ in Latvia and to $38 \%$ in Lithuania (in 2011, the government debt slightly decreased to $42.6 \%$ for Latvia and Lithuania and increased to $38.5 \%$ for Lithuania). Though those figures satisfied the Maastricht criterion, i.e. they did not exceed $60 \%$ of GDP, they were increasing very fast from 2009 (Fig. 10). The situation in those spheres was much better in Estonia. According to the data of the Eurostat database, though Estonia's foreign debt constantly rose during the crisis, it amounted to only $7.2 \%$ of GDP in 2009 , which was substantially less than required for a country to be admitted to the eurozone.

Figure 10. Government debt in the Baltic countries in 2004-2011 (\% of GDP)

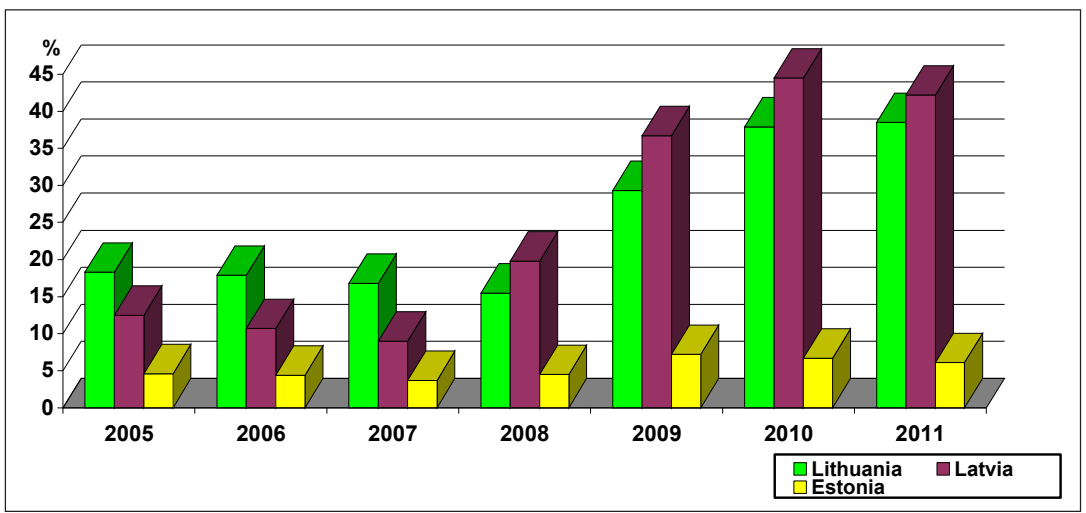

Source: Eurostat database.

Therefore, Estonia is the only one of all the EU Member States that satisfied the Maastricht criteria. It allowed the country to join the European Monetary Union from 1 January 2011. The most important factors which subsequently led to such remarkable achievements were a well contemplated economic policy, concentration of all national political powers upon one common aim and, as referred above, strict financial discipline. The support that Estonia receives from the Nordic countries cannot be underestimated either.

All of the three countries - Lithuania, Latvia and Estonia - are coping with the problem of emigration. If emigration processes are not suppressed in those countries, they will face serious economic difficulties in the future. Moreover, despite intensive emigration, unemployment has become a serious and large scale problem in the Baltic 
countries. According to the Eurostat database, maximum unemployment rate in those countries has reached unprecedented heights during the crisis and amounted to $17-20 \%$ (in $2010-16.9 \%$ in Lithuania, 16.9\% in Estonia and 19.8\% in Latvia). In 2011, the unemployment rate in those countries decreased (Fig. 11).

Figure 11. Unemployment rate in the Baltic States during 2005-2011

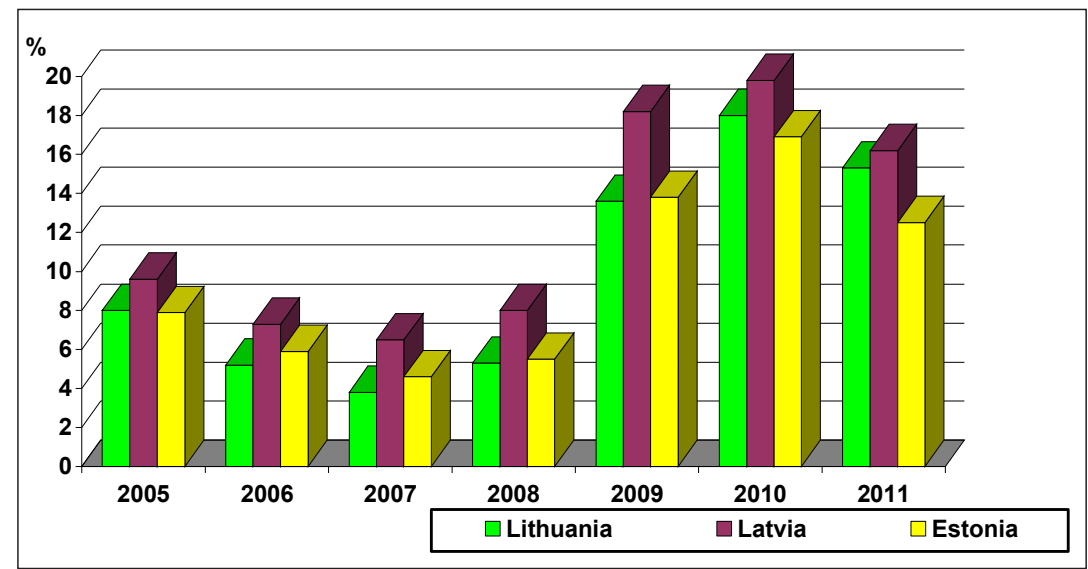

Source: Eurostat database.

According to the Eurostat database, in 2004-2008 inflation was constantly increasing in all of the three Baltic countries: from $1.2 \%$ in 2004 to $11.1 \%$ in 2008 in Estonia, from 3\% in 2004 to 10.6 in 2008 in Lithuania and from 6.2\% in 2004 to 15.3 in 2008 in Latvia. During 2008, the level of inflation fell down sharply, i.e. to $4.2 \%$ in Lithuania, to $0.2 \%$ in Estonia, and to $3.3 \%$ in Latvia (Fig. 12).

In 2010, the level of inflation increased, as the Baltic countries underwent inflationary pressures from abroad, determined by the growth of prices of raw materials, energy supplies and grain in global exchanges. Considering the fact that, compared to the EU average, common price level in the Baltic States is quite low (75\% in Latvia, $68 \%$ in Lithuania), it might be presumed that inflation in the Baltic States will be more rapid than in the euro zone. Therefore, in order to introduce the euro, those countries will have to cope with another serious problem and take steps to reduce the inflation rate.

Estonia is likely to be the most attractive to foreign investment among the Baltic countries. According to the data of the Eurostat database, direct foreign investment in Estonia was increasing even during the years of recession and in 2009 it reached almost $9 \%$ of GDP. Despite the slight decrease in direct foreign investment in Estonia in 2010, it still exceeded $8 \%$ of GDP. Meanwhile, direct foreign investment into the Latvian and Lithuanian economy was likely to decline (from $3.8 \%$ of GDP in 2008 to $0.3 \%$ of GDP in 2009 in Latvia and from $3.9 \%$ of GDP in 2008 to $0.9 \%$ of GDP in 2009 in Lithuania) and in 2010 it reached negative values. 
Figure 12. Inflation rate in the Baltic States during 2001-2012

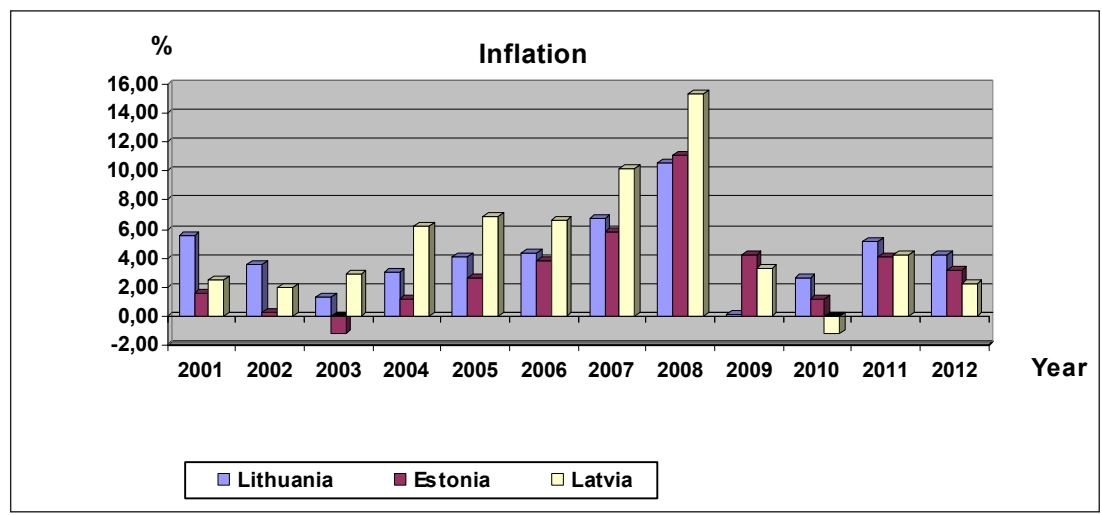

Source: Eurostat database.

Thus, among the Baltic States, Estonia is the most attractive for investment, with the most effective public sector, the situation of public finances not facing any problems, and coherent economic policy. From other points of view, Estonia only slightly differs from the other Baltic countries.

\section{Conclusions}

Domestic and external reasons have invoked Lithuania's economic crisis. Small countries of open economy as the Baltic countries had no chance of avoiding the effect of the global crisis on their economy, but deliberate economic policy of the government would have allowed avoiding the consequences of the global crisis for the country's economy. The economic policy of the Lithuanian government was not distinguished by foresight before and during the crisis. Formation of the budget deficit and tax reductions in the conditions of rapid economic growth contradicted the economic logic and had negative consequences for the country's economy with the onset of the crisis. Limiting fiscal policy of the former government with a view to stabilise state finances under current conditions was in principle correct. However, the measures to implement such a policy were not deliberate enough and proved to be unbalanced. That kind of policy created additional economic and social problems that could have been avoided by implementing a deliberate and long-sighted economic policy of the country.

Although Estonia pursued an expedient fiscal policy before the crisis and accumulated fiscal reserves, the character of macroeconomic processes in all of the Baltic countries was very similar and differed insignificantly. It is true that the accumulated financial reserves permitted Estonia to avoid additional difficulties in the sphere of public finances confronted by the Lithuanian and Latvian economies.

Politicians, economists and financial specialists should exhaustively study the lessons of the current crisis in order to avoid future mistakes. 


\section{References}

1. Commission of the European Communities (2008). From Financial Crisis to Recovery: A European Framework for Action: Communication from the Commission [accessed on 17 January 2013] <wp/2009/wp09125.pdf>.

2. Dash, M. (2001) Tulipomania. The Story of the World's Most Coveted Flower and the Extraordinary Passions it Aroused. Three Rivers Press.

3. Davulis, G. (2003). The development of the legal framework regulating foreign investment in the Republic of Lithuania: and its impact on the investment process. Jurisprudencija, 47 (39), 97-109.

4. Davulis, G. (2012). Lithuanian economic policy in the context of global crisis. Management Journal, 2012, 2(21), p. 83-94. Lithuanian Business University of Applied Sciences. ISSN 1648-7974. Klaipèda, 2012.

5. Eichengreen, B., O'Rourke, K. H. (2010). What do the new data tell us? Researchbased policy analysis [last accessed on 21 January 2013] <http://www.voxeu.org/ index.php?q=node/3421>.

6. Embassy of the Republic of Latvia in Vilnius. Programme for the Stabilisation and Revival of the Latvian Economy [last accessed on 6 December 2012] <http://www. am.gov.lv/lt/Vilnius/Ambasada $>$.

7. Eurostat database (2013). Economy and finance [last accessed on 2 February 2013] <http://epp.eurostat.ec.europa.eu/portal/page/portal/eurostat/home/>

8. Feldstein, M. et al. (1991). The Risk of Economic crisis. Chicago, London: The University of Chikago Press.

9. Felton A., Carman M. Reinhart (2008). First Global Financial Crisis of the 21st Century. A Voxeu. Org. Publication. London, UK: Centre for Economic Policy.

10. Jakeliūnas, S. (2010). The Anatomy of the Lithuanian Crisis. Kaunas: Kitos Knygos.

11. Lithuanian Department of Statistics (2013). Economy and Finance [last accessed on 21 February 2013] <http://www.stat.gov.lt/lt>

12. Lithuanian Department of Statistics (2013). International Trade [last accessed on 24 February 2013] <http://www.stat.gov.lt/lt>

13. Sharkinas, R. Lessons of the Global Financial Crisis for Lithuania. (2008). Money Studies. Lietuvos Bankas, No 2., p. 93-96.

14. Rakauskienè O. G., Krinickienè, E. (2009). The Anatomy of the Global Financial Crisis. Intellectual Economics, Vilnius: Mykolas Romeris University, 2009, No 2(6), p. 116-128.

15. Romer C. (2009). Lessons from the Great Depression for Economic Recovery. Washington. Brukling Institute [last accessed on 9 January 2013] <http://www. brooklings.edu>

16. Rosenberg, Ch. B. (2008). The Baltic Party Need Not End in a Bust. IMF Survey Magazine: Countries and Regions [last accessed on 16 December 2012] <http://www. imf.org/external/pubs/ft/survey/so/2008/CAR021908A.htm>.

17. Sylla, R. (2009). Lessons for the Five US crises: 1792, 1837-1842, 1873, 1907 and 19301933 [last accessed on 18 December 2012] <http://www ibf-frankfurt de/Slides_Sylla_ Symp_IBF_10Jun2009>. 
18. Soros, G. (2008). The New Paradigm for Financial Markets. The Crisis of 2008 for financial markes. New York, 2008.

19. Stiglitz, J. E. (2006). Making Globalization Work: The Economics and Social Review. USA. Columbia University.

\section{BALTIJOS ŠALIUU MAKROEKONOMINĖS SITUACIJOS BEI VYRIAUSYBIŲ EKONOMINĖS POLITIKOS KRIZĖS LAIKOTARPIU VERTINIMAS}

Santrauka. Straipsnyje nagrinejama ekonominè padètis Lietuvoje bei kitose Baltijos šalyse, šių šalių vyriausybių vykdomos ekonominès politikos priemonių ịtaka šių valstybių makroekonominiams procesams iki ekonominès krizès bei krizès laikotarpiu. Ikikriziniu laikotarpiu Lietuvos bei kitų Baltijos šalių ekonomikos sparčiai augo. Mažejantis nedarbas, augančios pajamos, tvirta valiuta, Europos Sajungos finansine parama buvo svarbiausi šio augimo veiksniai. Šie veiksniai, taip pat naryste Europos Sąungoje formavo, kaip dabar jau akivaizdu, ne visai pagrịstus lūkesčius dèl šalies ateities. Vedami šių lūkesčiu tiek įmonès, tiek namų ūkiai vis daugiau èmè skolintis vartojimui ir verslui, o ir bankai teike paskolas už patrauklias palūkanas. Didžioji namų ūkio gautų paskolų dalis buvo nukreipta ị nekilnojamojo turto rinką. Šị procesą skatino ir valstybès suteiktos mokesčiu lengvatos būsto paskoloms. Lietuvos banko duomenimis šių paskolų portfelis prieš krizę sudare daugiau kaip pusę visų paskolų namų ūkiams portfelio. Tokia kredito ekspansija turèjo lemiamos įtakos „burbului“ Lietuvos nekilnojamojo turto rinkoje susiformuoti. Šalies ekonomikos augimą nutraukè pasaulinė ekonomikos krizè, Lietuvą ji pasiekė $2008 \mathrm{~m}$. Analogiška situacija buvo ir kitose Baltijos šalyse. Remiantis Statistikos departamento prie Lietuvos Respublikos Vyriausybès duomenimis analizuojamos šalies makroekonominès tendencijos prieš krizę ir krizès metu, aptariamos šalies vyriausybių ekonominès politikos priemonès nagrinèjamu laikotarpiu. Straipsnyje aptariamos ir kitų Baltijos šalių antikrizinès priemonés. Remiantis Eurostato duomenų baze atlikta Baltijos šalių makroekonominių procesų palyginamoji analizė prieš krizę ir krizès laikotarpiu. Atlikta analizė parode, jog visų Baltijos šalių makroekonominès tendencijos buvo panašios, be esminių skirtumų, išskyrus viešųjų finansų sferą, kur Estija turèjo akivaizdų pranašumą tiek palyginus su Lietuva, tiek ir su Latvija.

Gediminas DAVULIS - professor at the Department of Economics, Faculty of Economics and Finance Management, Mykolas Romeris University. Research interests: analysis and modelling of macroeconomic processes, problems of public sector economy, self-government in the public sector, banking.

Gediminas DAVULIS - Mykolo Romerio universiteto Ekonomikos ir finansų valdymo fakulteto Ekonomikos katedros profesorius, daktaras. Tyrimų sritys: makroekonominių procesų modeliavimas ir analizé, viešojo sektoriaus ekonomikos problemos, savivalda viešajame sektoriuje, bankininkystè. 